Pol. J. Food Nutr. Sci., 2019, Vol. 69, No. 2, pp. 119-127

DOI: $10.31883 /$ pjfns-2019-0011 http://journal.pan.olsztyn.pl

Original research article

Section: Food Quality and Functionality

\title{
Functional Properties of Enzymatic Hydrolysate and Peptide Fractions from Perilla Seed Meal Protein
}

\author{
Bo Yeon Park, Kyung Young Yoon*
}

\author{
Department of Food and Nutrition, Yeungnam University. Gyeongsan, Gyeongbuk 38547, Korea
}

Key words: perilla seed meal, enzymatic hydrolysate, peptide, ultrafiltration, agricultural by-products, physical property

The present study aimed to decompose perilla seed meal (PSM) proteins via enzymatic degradation and to evaluate the functional properties of the resulting enzymatic hydrolysate and peptide fractions for the utilization of PSM, a by-product in the production of perilla seed oil. PSM protein hydrolysate was fractionated based on molecular weight using an ultrafiltration system, and the physical properties required to utilize the hydrolysate and peptide fractions as functional food components were determined. The enzymatic hydrolysate and peptide fractions showed higher solubility, oil absorption capacity, and emulsifying and foaming properties than protein isolates. In particular, peptide fractions below the $5 \mathrm{kDa}$ showed high solubility, emulsifying activity, and foaming capacity. Therefore, these peptide fractions are ideal as functional raw materials and substitutes that can be used to improve the quality of various processed food products and protein supplements.

\section{INTRODUCTION}

Perilla (Perilla frutescens var. Japonica HARA) is a seedling of a perennial plant belonging to the family Lamiaceae and is cultivated in some Asian countries such as Korea, China, and Japan [Meng et al., 2009a]. Perilla leaves are used as a fresh vegetable and to process pickles due to their unique scent. Perilla seeds were also considered as an interesting oil source for non-food uses and this variety has become widely cultivated in China and Korea. Perilla is not only used as a food ingredient but also for skin creams, soaps, and medicinal preparations, because of its recognized bioactivities, such as antioxidant, anti-allergic, anti-inflammatory, and anti-HIV-1 activity [Meng et al., 2009b]. In particular, perilla oil has excellent physiological functions such as lowering blood pressure, improving thrombosis, and inhibiting cancer cell proliferation [Mohammad, 2011], and perilla cultivation is increasing due to an increase of perilla oil consumption. Perilla seed meal (PSM), a byproduct of the production of perilla oil, is expected to be very useful as a functional food component because it contains high amounts of proteins and active ingredients [Di Bernardini et al., 2011].

Enzymatic hydrolysates, such as sugars, proteins, and lipids, are incorporated in the diets of individuals or patients suffering from impaired metabolic conditions. Protein hydrolysates have long been used in various processing applications, including dietary supplements for athletes and elderly people who need protein. Furthermore, they are used in animal feed to replace expensive protein sources [Schmidl et al., 1994;
Córdova-Murueta \& García-Carreño, 2002]. Hydrolysates containing low molecular weight peptides are easier to digest and absorb than long polymeric proteins and are widely available in various foods and processed products [Megias et al., 2009]. Peptides produced via enzymatic hydrolysis of food proteins exhibit physicochemical properties that are different from those of the original proteins because of lower molecular weights and exposure of hydrophobic residues caused by changes in the molecular structure, while maintaining physiological activity. Peptides present in food products exert biological control functions and provide nutritional value by supplying amino acids. In addition, peptides have excellent emulsifying properties and desired physical properties, such as gel-forming ability, solubility, viscosity, and emulsion properties, and strong affinity fat, and are thus ideal components of food products, such as sports drinks, dietetic foods, and health supplements [Chalamaiah et al., 2012; Benitez et al., 2008]. Various bioactive peptides have been produced from proteins, and their potential use as a functional food material has been proposed.

Therefore, in the present study, PSM protein hydrolysate was prepared via enzymatic degradation, and the peptides from the hydrolysate were fractionated based on the molecular weight using an ultrafiltration system. The amino acid composition and physical properties, including solubility, emulsification, foaming, oil retention, and water absorption properties, of the protein hydrolysate and peptide fractions were evaluated to serve as the basis for the utilization of PSM as functional ingredients in food products.

\footnotetext{
* Corresponding Author: Tel: +82-53-810-2878; Fax: +82-53-810-4666;

E-mail: yoonky2441@ynu.ac.kr 


\section{MATERIAL AND METHOD}

\section{Materials}

The PSM was obtained from Queensbucket Co. (Seoul, Korea) and ground and stored in a deep freezer (MDF-435, Sanyo, Tokyo, Japan) at $-42^{\circ} \mathrm{C}$ for use in subsequent experiments. The proximate composition of PSM was measured according to methods of Bhattacharjee et al. [2013] and Park \& Yoon [2014] with some modifications. Moisture content was measured using an infrared moisture analyzer (FD-720, Kett, Tokyo, Japan). The contents of crude protein and crude fat were determined using a Micro Kjeldahl system (Distillation Unit B-323, Buchi, Flawil, Switzerland) and an auto fat extraction system (Soxtec 2050, Foss, Sweden), respectively. Crude fiber content was analyzed with a raw fiber extractor (Fiber test F-6, Raypa, Spain). Crude ash content was determined by weighing the remaining inorganic residue after being completely burned at a temperature of $550^{\circ} \mathrm{C}$ in a muffle furnace. The total carbohydrate content (\%) in the PSM was determined by the method involving the summing up of the total values of crude protein, crude fat, crude fiber, and crude ash constituents of the sample and subtracting it from 100. The moisture content of PSM was $26.55 \%$, and crude protein, crude fiber, crude fat, crude ash, and carbohydrate contents were 45.50, 30.74, 18.69, 4.81, and $0.27 \%$ dry weight, respectively.

\section{Preparation of perilla seed meal (PSM) protein isolate}

The PSM protein isolate was prepared according to the alkaline extraction and acid precipitation method of Gnanasambandam \& Heitiarachchy [1995] with slight modifications. The PSM was added with distilled water at a ratio of 1:10 (w/v) and stirred in a shaking water bath (BS-11, JeioTech, Seoul, Korea) at $25^{\circ} \mathrm{C}$ for $1 \mathrm{~h}$; the $\mathrm{pH}$ of the mixture was adjusted to 10.0 with $1 \mathrm{~N} \mathrm{NaOH}$. The resulting slurry was incubated at $25^{\circ} \mathrm{C}$ for $1 \mathrm{~h}$ and centrifuged for $17,000 \times g$ for $30 \mathrm{~min}$ at $4^{\circ} \mathrm{C}$ to obtain the supernatant. The supernatant was adjusted to $\mathrm{pH} 4.0$ with $1 \mathrm{~N} \mathrm{HCl}$ and incubated at $25^{\circ} \mathrm{C}$ for $30 \mathrm{~min}$ to precipitate the proteins. The precipitated proteins were then collected by centrifugation at $16,000 \times g$ for $30 \mathrm{~min}$, and the residue was homogenized with a homogenizer (AM-1, Nihonseiki Kaisha LDD, Nissei, Japan) by the addition of distilled water equivalent to twice the weight of the residue. The $\mathrm{pH}$ of the mixture was adjusted to 7.0, then the mixture was lyophilized using a freeze dryer (FD-1, Eyela, Tokyo, Japan), and used as the protein isolate for hydrolysate preparation.

\section{Preparation of PSM protein hydrolysate and membrane fractions}

The PSM protein hydrolysate was prepared following the method of our previous study to find optimal hydrolysis conditions [Park \& Yoon, 2018]. As a result of previous experiments, optimal hydrolysis conditions of the PSM protein isolate were determined to be $\mathrm{pH} 7.0$, hydrolysis temperature of $50^{\circ} \mathrm{C}$, hydrolysis time of $4 \mathrm{~h}$, and enzyme concentration of $10 \mathrm{U}$ using Flavourzyme (Novo Nordisk Co., Bagsvaerd, Denmark). Thus, the following hydrolysis conditions were used in the present study: PSM protein isolates $(5 \% \mathrm{w} / \mathrm{v})$ were suspended in $25 \mathrm{~mL}$ of $0.1 \mathrm{M}$ phosphate buffer ( $\mathrm{pH} 7.0$ ) in a reaction vessel equipped with a stirrer and hydrolyzed with $10 \mathrm{U}$ of Flavourzyme at $50^{\circ} \mathrm{C}$ for $4 \mathrm{~h}$. After enzymatic hydrolysis, the reaction mixture was boiled at $95^{\circ} \mathrm{C}$ for $10 \mathrm{~min}$ to inactivate the enzyme and then centrifuged at 18,000 $\times g$ for $20 \mathrm{~min}$. A part of the supernatant (hydrolysate solution) was passed through ultrafiltration membranes with varying molecular weight cut-offs (3, 5, and $10 \mathrm{kDa})$ using an Amicon Stirred Ultrafiltration Cell (8050, Millipore, Bedford, MA, USA). The permeate from each molecular weight cutoff membrane was collected as $<3,3-5,5-10$, and $>10 \mathrm{kDa}$ peptide fractions. The hydrolysate solution and all permeates were freeze-dried and stored at $-42^{\circ} \mathrm{C}$ for subsequent determination of physical properties.

\section{Amino acid analysis}

Amino acid composition of protein isolate, hydrolysate, and peptide fractions was determined using an amino acid analyzer (Biochrom 30, Biochrom, Cambridge, UK). The sample ( $30 \mathrm{mg}$ ) was mixed with $3 \mathrm{~mL}$ of $6 \mathrm{~N} \mathrm{HCl}$ and then hydrolyzed at $110^{\circ} \mathrm{C}$ for $24 \mathrm{~h}$. The hydrolyzed mixture was filtered with a glass wool to remove the residue. The filtrate was concentrated under reduced pressure using a rotary vacuum evaporator (R-124, Buchi, Flawil, Swizerland) at $45^{\circ} \mathrm{C}$, and then diluted to $100 \mathrm{~mL}$ with a sodium citrate buffer (pH 2.2). The filtrate filtered through a $0.45 \mu \mathrm{m}$ membrane filter (Millipore, Billeria, MA, USA) was used as a sample for amino acid analysis. The amino acid content was expressed as a percentage of total amino acids in the sample.

\section{Solubility measurements}

The solubility of each sample was measured following the method of Nalinanon et al. [2011] with some modifications. The sample was mixed with distilled water at 1:100 (w/v) and stirred for $1 \mathrm{~h}$. Each dispersion was adjusted to $\mathrm{pH} \mathrm{2,} \mathrm{4,} \mathrm{6,} \mathrm{8,} \mathrm{and} 10$ and subsequently centrifuged at 4,000 $\times \mathrm{g}$ for $20 \mathrm{~min}$. The protein content of the supernatant was measured by performing a bicinchoninic acid assay [Jang et al. 2016] and expressed as the percentage of the total protein content in the sample, using the following equation (1):

Solubility $(\%)=\frac{\text { Protein content in supernatant }}{\text { Total protein content in sample }} \times 100$

\section{Water and oil absorption capacity}

Water and oil absorption capacities were measured according to the method of Beuchat [1977]. Each sample (1 g) was mixed with $10 \mathrm{~mL}$ of distilled water, vortexed, and incubated at room temperature for $30 \mathrm{~min}$. After centrifugation at $3,000 \times g$ for $15 \mathrm{~min}$, the volume of the supernatant was measured using a $10-\mathrm{mL}$ graduated cylinder. Water absorption capacity (WAC) and oil absorption capacity (OAB) were expressed as $\mathrm{g}$ of distilled water or soybean oil adsorbed to $1 \mathrm{~g}$ of sample.

\section{Emulsifying properties}

The emulsifying activity was determined following the method of Yim \& Lee [2000] with modifications. Each sample $(1 \mathrm{~g})$ was mixed with $100 \mathrm{~mL}$ of distilled water, dispersed by vortexing, and the $\mathrm{pH}$ of the dispersion was ad- 
justed to 2, 4, 6, 8, and 10 . Then, $20 \mathrm{~mL}$ of the dispersion was added to $20 \mathrm{~mL}$ of soybean oil and dispersed for $5 \mathrm{~min}$ to form an emulsion. The emulsion was centrifuged at $1,100 \times g$ for $5 \mathrm{~min}$, and the height of the emulsified layer and the total height of the tube were determined. The emulsifying activity was measured according to the following equation (2):

$\begin{aligned} & \text { Emulsifying } \\ & \text { activity }(\%)\end{aligned}=\frac{\text { Height of emulsified layer }}{\text { Height of total contents in the tube }} \times 100$

For the measurement of emulsion stability, the emulsion was prepared by the same method as that used for emulsifying activity. The emulsion was then heated in a hot water bath at $80^{\circ} \mathrm{C}$ for $30 \mathrm{~min}$, cooled to $15^{\circ} \mathrm{C}$ and centrifuged at 1,100 $\times g$ for $5 \mathrm{~min}$, and the emulsion layer was measured. Emulsion stability was expressed using equation (3):

$\begin{aligned} & \text { Emulsion } \\ & \text { stability }(\%)\end{aligned}=\frac{\text { Height of emulsified layer after heating }}{\text { Height of the initial emulsified layer }} \times 100$

\section{Foaming properties}

Determination of foaming capacity was determined by a modified method of Sathe \& Salunkhe [1981]. The sample $(1 \mathrm{~g})$ was added to $99 \mathrm{~mL}$ of distilled water, and each solution was adjusted to $\mathrm{pH} 2,4,6,8$, and 10 , respectively. The mixture was transferred to a graduated cylinder and bubbled at 10,000 rpm for $30 \mathrm{~s}$ using a homogenizer (AM-1, Nihonseiki Kaisha LDD, Nissei, Japan), and the corresponding increase in volume $(\mathrm{mL})$ was measured.

Foam stability was measured by comparing the foam volume at constant time to the initial foam volume of samples. In other words the foam was formed in the same method as that of foaming capacity and the initial volume of the bubble was measured. The foam was allowed to stand for 30 and $60 \mathrm{~min}$ at room temperature, and its volume was measured again. Foam stability was calculated according to equation (4):

$$
\text { Foam stability }(\%)=\frac{\mathrm{B}-\mathrm{A}}{\mathrm{B}} \times 100
$$

where A represents the volume after standing $(\mathrm{mL})$, and B represents volume before whipping $(\mathrm{mL})$.

\section{Statistical analysis}

Results were expressed as the mean and standard deviation of triplicate experiments. Statistical analysis was performed using SPSS (Ver. 21, Chicago, IL, USA) statistical program. Statistical significance was considered at $\mathrm{p}<0.05$. Significant differences between the mean values of the tests were verified by conducting Duncan's multiple range test.

\section{RESULTS AND DISCUSSION}

\section{Amino acid composition}

The amino acid composition of protein isolate, hydrolysate, and peptide fractions is presented in Table 1. All samples were characterized by high levels of aspar- tic acid (7.92 $\pm 13.26-13.26 \pm 1.13 \%)$ and glutamic acid $(19.61 \pm 27.03-28.61 \pm 0.24 \%)$, i.e. negatively charged amino acid, which would suggest that PSM protein hydrolysate possessed acidic characteristic. In addition, all samples contained high levels of lysine and arginine, and, especially, the lysine content of $<3 \mathrm{kDa}$ fraction was $14.02 \pm 4.52 \%$, which was significantly the highest in the samples. It is important to note that lysine is nutritionally important as cases of growth retardation in children increase as a consequence of deficiency in dietary lysine [Tan et al., 2014]. All samples also contained the high amount of the essential amino acids (EAA), and the EAA content of peptide fractions increased with decreasing molecular weight. For example, EAA contents of protein isolate, hydrolysate, $>10 \mathrm{kDa}, 5-10 \mathrm{kDa}, 3-5 \mathrm{kDa}$, and $<3 \mathrm{kDa}$ peptide fractions were $29.26 \pm 0.11,30.93 \pm 1.98$, $30.34 \pm 0.51,37.75 \pm 0.03,38.18 \pm 0.17$, and $44.91 \pm 0.76 \%$, respectively. Hence, the results suggested that hydrolysate and peptide fractions could be used as an alternative source for cereal-based foods which are low in lysine. These results indicated also that peptide fractions obtained from PSM could be used as dietary protein supplements within food formulations to design protein products. Protein isolate and hydrolysate showed the higher levels of glutamic acid, arginine, and glycine contents compared to peptide fractions, while peptide fractions except for $>10 \mathrm{kDa}$ fraction had higher contents of lysine, leucine, valine, and phenylalanine than protein isolate and hydrolysate. As a result, the peptide fractions except for the $>10 \mathrm{kDa}$ fraction showed significantly higher contents of hydrophobic amino acids (25.9 $\pm 0.91-30.79 \pm 3.79 \%)$ than the protein isolate $(18.73 \pm 0.07 \%)$ and hydrolysate $(22.57 \pm 1.06 \%)$. Amino acid composition has been reported to influence the structure, hydrophobicity, and functionality of peptides [Kimatu et al., 2017]. Therefore, it could be expected that the physicochemical and functional properties of protein isolate and hydrolysate would be different from these of the peptide fractions.

\section{Solubility}

The solubilities of the hydrolysate and peptide fractions obtained from PSM proteins were measured to evaluate the potential use of PSM in various food applications. Results were compared relative to the protein isolates (Table 2). The solubility of protein isolate, hydrolysate, and peptide fractions obtained via ultrafiltration ranged from $22.81 \pm 0.61 \%$ to $39.21 \pm 1.27 \%, \quad 38.84 \pm 1.39 \%$ to $57.35 \pm 1.97 \%$, and $31.79 \pm 0.93 \%$ to $61.73 \pm 1.77 \%$, respectively. The solubilities of the hydrolysate and peptide fractions were relatively higher than those of protein isolates, and fractions with smaller molecular weights showed higher solubilities. In particular, the $<3 \mathrm{kDa}$ peptides showed the highest solubilities among peptide fractions under all $\mathrm{pH}$ conditions, and the highest solubility $(61.73 \pm 1.77 \%)$ was observed at $\mathrm{pH} 10.0$. These results are consistent with the previous findings by Lee et al. [1995], in which proteins with smaller molecular sizes were found to exhibit higher solubility. The peptide permeates prepared via ultrafiltration and papain modification treatment of soy protein were almost completely soluble at all $\mathrm{pH}$ values, except for pH 5.0 [Wu et al., 1998]. In general, the degradation of proteins into smaller peptides leads to the forma- 
TABLE 1. Amino acid composition of protein isolate, hydrolysate, and peptide fractions obtained from perilla seed meal.

\begin{tabular}{|c|c|c|c|c|c|c|}
\hline Amino acid & Protein isolate & Hydrolysate & $>10 \mathrm{kDa}$ & $5-10 \mathrm{kDa}$ & $3-5 \mathrm{kDa}$ & $<3 \mathrm{kDa}$ \\
\hline Aspartic acid & $10.40 \pm 0.08^{\mathrm{b}}$ & $13.26 \pm 1.13^{\mathrm{a}}$ & $7.92 \pm 0.22^{\mathrm{d}}$ & $10.44 \pm 0.35^{\mathrm{b}}$ & $9.67 \pm 0.20^{\mathrm{c}}$ & $10.84 \pm 0.21^{b}$ \\
\hline Threonine & $2.85 \pm 0.19^{\mathrm{bc}}$ & $2.89 \pm 0.12^{\mathrm{b}}$ & $2.43 \pm 0.05^{\mathrm{d}}$ & $3.44 \pm 0.30^{\mathrm{a}}$ & $3.43 \pm 0.04^{\mathrm{a}}$ & $2.64 \pm 0.14^{\mathrm{c}}$ \\
\hline Serine & $4.73 \pm 0.11^{\mathrm{cd}}$ & $4.85 \pm 0.01^{\mathrm{c}}$ & $5.07 \pm 0.03^{\mathrm{b}}$ & $5.73 \pm 0.11^{\mathrm{a}}$ & $5.82 \pm 0.13^{\mathrm{a}}$ & $4.62 \pm 0.19^{d}$ \\
\hline Glutamic acid & $27.03 \pm 0.07^{\mathrm{b}}$ & $25.59 \pm 0.01^{\mathrm{c}}$ & $28.61 \pm 0.24^{\mathrm{a}}$ & $22.33 \pm 0.33^{\mathrm{d}}$ & $20.5 \pm 0.53^{\mathrm{e}}$ & $19.61 \pm 0.04^{\mathrm{f}}$ \\
\hline Proline & n.d & n.d & n.d & n.d & n.d & n.d \\
\hline Glycine & $6.92 \pm 0.04^{\mathrm{a}}$ & $5.73 \pm 0.01^{\mathrm{b}}$ & $5.97 \pm 0.09^{\mathrm{b}}$ & $4.41 \pm 0.23^{\mathrm{d}}$ & $4.98 \pm 0.07^{\mathrm{c}}$ & $4.06 \pm 0.60^{\mathrm{e}}$ \\
\hline Alanine & $3.70 \pm 0.07^{\mathrm{c}}$ & $4.73 \pm 0.07^{\mathrm{b}}$ & $3.57 \pm 0.19^{\mathrm{cd}}$ & $4.59 \pm 0.36^{\mathrm{b}}$ & $4.84 \pm 0.24^{\mathrm{b}}$ & $5.59 \pm 0.39^{\mathrm{a}}$ \\
\hline Cystine & n.d & n.d & n.d & n.d & n.d & n.d \\
\hline Valine & $3.62 \pm 0.09^{\mathrm{cd}}$ & $3.45 \pm 0.21^{\mathrm{c}}$ & $2.98 \pm 0.01^{\mathrm{d}}$ & $4.64 \pm 0.25^{\mathrm{b}}$ & $4.63 \pm 0.11^{\mathrm{b}}$ & $5.71 \pm 0.46^{\mathrm{a}}$ \\
\hline Tryptophan & n.d & n.d & n.d & n.d & n.d & n.d \\
\hline Methionine & $1.98 \pm 0.02^{\mathrm{bc}}$ & $1.75 \pm 0.15^{\mathrm{c}}$ & $3.40 \pm 0.11^{\mathrm{a}}$ & $2.01 \pm 0.11^{\mathrm{bc}}$ & $1.00 \pm 0.01^{\mathrm{d}}$ & $2.30 \pm 0.91^{\mathrm{b}}$ \\
\hline Isoleucine & $1.42 \pm 0.05^{\mathrm{c}}$ & $1.95 \pm 0.60^{\mathrm{abc}}$ & $1.70 \pm 0.47^{\mathrm{bc}}$ & $2.04 \pm 0.34^{\mathrm{ab}}$ & $2.16 \pm 0.01^{\mathrm{ab}}$ & $2.47 \pm 0.71^{\mathrm{a}}$ \\
\hline Leucine & $4.11 \pm 0.04^{\mathrm{e}}$ & $5.25 \pm 0.41^{\mathrm{d}}$ & $5.10 \pm 0.16^{\mathrm{d}}$ & $6.30 \pm 0.30^{c}$ & $7.47 \pm 0.04^{\mathrm{b}}$ & $8.02 \pm 0.71^{\mathrm{a}}$ \\
\hline Tyrosine & $2.86 \pm 0.05^{\mathrm{a}}$ & $2.38 \pm 0.28^{\mathrm{a}}$ & $2.91 \pm 0.13^{\mathrm{a}}$ & $2.52 \pm 0.04^{\mathrm{a}}$ & $3.13 \pm 0.11^{\mathrm{a}}$ & $2.38 \pm 1.33^{\mathrm{a}}$ \\
\hline Phenylalanine & $3.90 \pm 0.10^{\mathrm{d}}$ & $5.45 \pm 0.07^{c}$ & $3.57 \pm 0.04^{\mathrm{e}}$ & $6.32 \pm 0.24^{\mathrm{b}}$ & $6.66 \pm 0.10^{\mathrm{ab}}$ & $6.71 \pm 0.61^{\mathrm{a}}$ \\
\hline Histidine & $3.59 \pm 0.08^{\mathrm{ab}}$ & $4.04 \pm 1.29^{\mathrm{a}}$ & $3.49 \pm 0.00^{\mathrm{ab}}$ & $3.15 \pm 0.09^{\mathrm{b}}$ & $3.63 \pm 0.01^{\mathrm{ab}}$ & $3.05 \pm 0.22^{\mathrm{b}}$ \\
\hline Lysine & $7.80 \pm 0.21^{\mathrm{bc}}$ & $6.16 \pm 2.15^{\mathrm{c}}$ & $7.68 \pm 0.02^{\mathrm{bc}}$ & $9.84 \pm 0.36^{\mathrm{b}}$ & $9.19 \pm 0.04^{b}$ & $14.02 \pm 4.52^{\mathrm{a}}$ \\
\hline Arginine & $15.09 \pm 0.09^{\mathrm{a}}$ & $12.54 \pm 0.64^{\mathrm{bc}}$ & $15.59 \pm 0.02^{\mathrm{a}}$ & $12.23 \pm 0.27^{\mathrm{c}}$ & $12.87 \pm 0.35^{\mathrm{b}}$ & $7.99 \pm 0.65^{\mathrm{d}}$ \\
\hline HHA & $18.73 \pm 0.07^{\mathrm{d}}$ & $22.57 \pm 1.06^{\mathrm{c}}$ & $20.32 \pm 0.39^{c}$ & $25.90 \pm 0.91^{\mathrm{b}}$ & $26.77 \pm 0.07^{\mathrm{b}}$ & $30.79 \pm 3.79^{\mathrm{a}}$ \\
\hline PCAA & $26.48 \pm 0.38^{\mathrm{b}}$ & $22.74 \pm 0.23^{\mathrm{a}}$ & $26.75 \pm 0.07^{b}$ & $25.23 \pm 0.01^{\mathrm{b}}$ & $25.70 \pm 0.39^{b}$ & $25.06 \pm 3.64^{b}$ \\
\hline NCAA & $37.43 \pm 0.01^{\mathrm{b}}$ & $38.85 \pm 1.14^{\mathrm{a}}$ & $36.53 \pm 0.01^{\mathrm{c}}$ & $32.77 \pm 0.68^{d}$ & $30.16 \pm 0.33^{\mathrm{e}}$ & $30.45 \pm 0.25^{\mathrm{e}}$ \\
\hline TEAA & $29.26 \pm 0.11^{\mathrm{d}}$ & $30.93 \pm 1.98^{c}$ & $30.34 \pm 0.55^{\mathrm{cd}}$ & $37.75 \pm 0.03^{b}$ & $38.18 \pm 0.17^{\mathrm{b}}$ & $44.91 \pm 0.76^{\mathrm{a}}$ \\
\hline
\end{tabular}

The amino acid content was expressed as the mean $\pm \mathrm{SD}(\mathrm{n}=3)$ as a percentage of the total amino acids. Values with different letters in the same row are significantly different at $\mathrm{p}<0.05$. HHA, hydrophobic amino acids-Ala, Vla, Ile, Leu, Phe, Try, Pro, Met and Cys; PCAA, positively charged amino acids-Arg, His and Lys; NCAA, negatively charged amino acids- Asp and Glu; TEAA, total essential amino acids. n.d, not detected.

TABLE 2. Solubilities of protein isolate, hydrolysate, and peptide fractions obtained from perilla seed meal at varying $\mathrm{pH}$ conditions.

\begin{tabular}{l|c|c|c|c|c}
\hline \multirow{2}{*}{ Fraction } & \multicolumn{5}{c}{ Solubility $(\%)$} \\
\cline { 2 - 6 } & $\mathrm{pH} 2.0$ & $\mathrm{pH} 4.0$ & $\mathrm{pH} 6.0$ & $\mathrm{pH} 8.0$ & $\mathrm{pH} 10.0$ \\
\hline Protein isolate & $37.81 \pm 0.88^{\mathrm{cA}}$ & $22.81 \pm 0.61^{\mathrm{dB}}$ & $37.86 \pm 1.07^{\mathrm{cA}}$ & $38.43 \pm 0.57^{\mathrm{dA}}$ & $39.21 \pm 1.27^{\mathrm{eA}}$ \\
Hydrolysate & $54.98 \pm 1.54^{\mathrm{aA}}$ & $38.24 \pm 1.39^{\mathrm{aB}}$ & $55.39 \pm 1.66^{\mathrm{abA}}$ & $56.25 \pm 1.66^{\mathrm{bA}}$ & $57.35 \pm 1.97^{\mathrm{cA}}$ \\
$>10 \mathrm{kDa}$ & $50.27 \pm 1.58^{\mathrm{bA}}$ & $31.79 \pm 0.93^{\mathrm{cB}}$ & $48.51 \pm 1.45^{\mathrm{bA}}$ & $49.58 \pm 1.48^{\mathrm{cA}}$ & $51.92 \pm 1.59^{\mathrm{dA}}$ \\
$5-10 \mathrm{kDa}$ & $50.63 \pm 2.31^{\mathrm{bB}}$ & $32.22 \pm 0.94^{\mathrm{cC}}$ & $50.49 \pm 1.59^{\mathrm{bB}}$ & $51.41 \pm 1.54^{\mathrm{cB}}$ & $56.04 \pm 1.60^{\mathrm{cA}}$ \\
$3-5 \mathrm{kDa}$ & $55.05 \pm 1.84^{\mathrm{aA}}$ & $36.40 \pm 0.95^{\mathrm{bB}}$ & $55.52 \pm 1.74^{\mathrm{abA}}$ & $56.34 \pm 1.68^{\mathrm{abA}}$ & $58.16 \pm 1.66^{\mathrm{bA}}$ \\
$<3 \mathrm{kDa}$ & $55.87 \pm 1.72^{\mathrm{aB}}$ & $39.82 \pm 1.07^{\mathrm{aC}}$ & $58.48 \pm 1.70^{\mathrm{aAB}}$ & $59.66 \pm 1.72^{\mathrm{aAB}}$ & $61.73 \pm 1.77^{\mathrm{aA}}$ \\
\hline
\end{tabular}

Mean \pm SD $(n=3)$. Values with different small letters in the same column are significantly different at $p<0.05$. Values with different capital letters in the same row are significantly different at $\mathrm{p}<0.05$.

tion of more soluble products [Klompong et al., 2017], since smaller peptides have increased the accessibility of hydrophilic groups, and facilitated the reaction of hydrophilic amino acid to the aqueous medium [Nguyen et al., 2017; Sarabandi et al., 2018]. The high solubility of the peptides obtained via ultrafiltration using molecular weight cut-off membranes is presumably caused by the exposure of all hydrophilic groups of small molecules to the aqueous environment [Wu 
et al., 1998]. Regarding the solubilities of the samples under various $\mathrm{pH}$ conditions, all samples showed the lowest solubilities at $\mathrm{pH} 4.0$, and solubility increased at $\mathrm{pH} 2.0$ and above $\mathrm{pH}$ 6.0. The above results are consistent with those reported by Tan et al. [2014], who showed that the solubilities of soybean and pinto bean protein isolates were the lowest at the $\mathrm{pH}$ range from 4.0 to 5.0. The low solubilities of protein hydrolysates and peptides at $\mathrm{pH} 4.0$ were attributed to the low solubilities of amino acids and proteins at isoelectric point, leading to the formation of precipitates [Singh et al., 2005]. Several factors are known to influence protein solubility, including surface charges, $\mathrm{pH}$, molecular size, ionic strength and type, and temperature of solvent. The $\mathrm{pH}$ is considered the most significant factor influencing protein solubility [Kinsella, 1979], and alkali treatment usually improves the solubility of proteins [Pearson, 1994]. Peptides obtained from the PSM protein hydrolysate showed higher solubilities than those of the protein isolates and thus could be used as components of various food products.

\section{Water and oil absorption capacity}

Water absorption capacities (WACs) of protein isolate, hydrolysate, and ultrafiltration fractions obtained from PSM are shown in Table 3. The highest WAC of protein isolates was $1.23 \pm 0.47 \mathrm{~g} / \mathrm{g}$, while the WAC of the hydrolysate was $0.68 \pm 0.05 \mathrm{~g} / \mathrm{g}$. The WACs of peptide fractions ranged from $0.72 \pm 0.07$ to $0.76 \pm 0.16 \mathrm{~g} / \mathrm{g}$, with no significant differences among the peptide fractions. The interactions of protein with water are important in relation to dispersibility or wettability, water absorption and binding, swelling, viscosity, gelation, and surfactant properties [Lee, 2015]. The oil adsorption capacities (OACs) of the hydrolysate $(2.45 \pm 0.21 \mathrm{~g} / \mathrm{g})$ and peptide fractions $(2.43 \pm 0.25-2.79 \pm 0.08 \mathrm{~g} / \mathrm{g})$ were higher than those of the protein isolates $(1.36 \pm 0.15 \mathrm{~g} / \mathrm{g})$, and the OAC of the peptide fraction tended to increase with decreasing molecular weight. Manak et al. [1980] reported that the OAC of soy protein isolates prepared via ultrafiltration was $2.52 \mathrm{~mL} / \mathrm{g}$, which is similar to those of the peptide fractions obtained via ultrafiltration. Hermansson [1975] reported that the $\mathrm{OAC}$ of proteins is influenced by $\mathrm{pH}$ and ion concentrations and is dependent on protein composition, amino acid ratios, and the presence of carbohydrates. In addition, oil/ water holding capacity relies on surface properties, overall charge density, thickness and hydrophobic/hydrophilic nature of the food particle [Dehnad et al., 2016]. From the above results, the peptide fractions from PSM showed lower WAC and higher OAC than protein isolate, which is considered to be related to the result that the peptide fraction with the smaller molecular weight had the higher content of hydrophobic amino acids. In other words, it is presumed that the hydrophobic peptides exposed by enzymatic hydrolysis are due to increased binding to the oil as compared to the interaction with water [Tan et al., 2014].

\section{Emulsifying properties}

Protein emulsifying activity is the ability of the protein to participate in emulsion formation and to stabilize the newly created emulsion. Emulsifying properties are useful functional characteristics which play an important role in the development of new sources of plant protein products for uses as foods [Cabra et al., 2008; Dehnad et al., 2016]. The emulsifying activities of protein isolate, hydrolysate, and peptide fractions obtained from PSM are shown in Table 4. The emulsifying activity of protein isolate ranged from $40.18 \pm 0.58 \%$ to $52.46 \pm 0.28 \%$. The emulsifying activity of the hydrolysates at various $\mathrm{pH}$ conditions ranged from $48.58 \pm 2.63 \%$ to $64.87 \pm 0.76 \%$, while those

TABLE 3. Water and oil absorption capacities of protein isolate, hydrolysate, and peptide fractions obtained from perilla seed meal.

\begin{tabular}{lcc}
\hline Fraction & $\begin{array}{c}\text { Water absorption } \\
\text { capacity }(\mathrm{g} / \mathrm{g})\end{array}$ & $\begin{array}{c}\text { Oil absorption } \\
\text { capacity }(\mathrm{g} / \mathrm{g})\end{array}$ \\
\hline Protein isolate & $1.23 \pm 0.47^{\mathrm{a}}$ & $1.36 \pm 0.15^{\mathrm{c}}$ \\
Hydrolysate & $0.68 \pm 0.05^{\mathrm{b}}$ & $2.45 \pm 0.21^{\mathrm{b}}$ \\
$>10 \mathrm{kDa}$ & $0.76 \pm 0.16^{\mathrm{b}}$ & $2.43 \pm 0.25^{\mathrm{b}}$ \\
$5-10 \mathrm{kDa}$ & $0.72 \pm 0.07^{\mathrm{b}}$ & $2.48 \pm 0.23^{\mathrm{b}}$ \\
$3-5 \mathrm{kDa}$ & $0.76 \pm 0.01^{\mathrm{b}}$ & $2.57 \pm 0.12^{\mathrm{ab}}$ \\
$<3 \mathrm{kDa}$ & $0.75 \pm 0.20^{\mathrm{b}}$ & $2.79 \pm 0.08^{\mathrm{a}}$ \\
\hline
\end{tabular}

Mean \pm SD $(n=3)$. Values with different small letters in the same column are significantly different at $\mathrm{p}<0.05$.

TABLE 4. Emulsifying activities of protein isolate, hydrolysate, and peptide fractions obtained from perilla seed meal at varying pH conditions.

\begin{tabular}{l|c|c|c|c|c}
\hline \multirow{2}{*}{ Fraction } & \multicolumn{5}{c}{ Emulsifying activity (\%) } \\
\cline { 2 - 6 } & $\mathrm{pH} 2.0$ & $\mathrm{pH} 4.0$ & $\mathrm{pH} 6.0$ & $\mathrm{pH} 8.0$ & $\mathrm{pH} 10.0$ \\
\hline Protein isolate & $52.46 \pm 0.28^{\mathrm{dA}}$ & $40.18 \pm 0.58^{\mathrm{cD}}$ & $45.79 \pm 0.45^{\mathrm{cC}}$ & $49.22 \pm 0.38^{\mathrm{cB}}$ & $49.65 \pm 0.78^{\mathrm{cB}}$ \\
Hydrolysate & $64.87 \pm 0.76^{\mathrm{aA}}$ & $48.58 \pm 2.63^{\mathrm{bC}}$ & $53.23 \pm 2.77^{\mathrm{abB}}$ & $54.93 \pm 3.55^{\mathrm{bB}}$ & $57.10 \pm 0.77^{\mathrm{abB}}$ \\
$>10 \mathrm{kDa}$ & $55.48 \pm 0.19^{\mathrm{cA}}$ & $47.77 \pm 2.74^{\mathrm{bB}}$ & $49.16 \pm 2.28^{\mathrm{bcB}}$ & $55.30 \pm 0.76^{\mathrm{bA}}$ & $55.33 \pm 0.27^{\mathrm{bA}}$ \\
$5-10 \mathrm{kDa}$ & $61.91 \pm 1.45^{\mathrm{bA}}$ & $49.23 \pm 3.02^{\mathrm{abB}}$ & $49.37 \pm 0.68^{\mathrm{bcB}}$ & $56.28 \pm 2.84^{\mathrm{abA}}$ & $56.97 \pm 5.65^{\mathrm{abA}}$ \\
$3-5 \mathrm{kDa}$ & $64.72 \pm 0.68^{\mathrm{aA}}$ & $50.67 \pm 2.74^{\mathrm{abC}}$ & $55.84 \pm 0.55^{\mathrm{aB}}$ & $56.05 \pm 0.50^{\mathrm{abB}}$ & $57.56 \pm 0.29^{\mathrm{abB}}$ \\
$<3 \mathrm{kDa}$ & $65.74 \pm 1.12^{\mathrm{aA}}$ & $55.26 \pm 4.03^{\mathrm{aB}}$ & $56.67 \pm 5.33^{\mathrm{aB}}$ & $60.07 \pm 3.10^{\mathrm{aAB}}$ & $60.63 \pm 2.56^{\mathrm{aAB}}$ \\
\hline
\end{tabular}

Mean \pm SD $(n=3)$. Values with different small letters in the same column are significantly different at $p<0.05$. Values with different capital letters in the same row are significantly different at $\mathrm{p}<0.05$. 
TABLE 5. Emulsion stabilities of protein isolate, hydrolysate, and peptide fractions obtained from perilla seed meal at varying pH conditions.

\begin{tabular}{l|c|c|c|c|c}
\hline \multirow{2}{*}{ Fraction } & \multicolumn{5}{c}{ Emulsion stability $(\%)$} \\
\cline { 2 - 6 } & $\mathrm{pH} 2.0$ & $\mathrm{pH} 4.0$ & $\mathrm{pH} 6.0$ & $\mathrm{pH} 8.0$ & $\mathrm{pH} 10.0$ \\
\hline Protein isolate & $44.04 \pm 0.82^{\mathrm{bA}}$ & $33.18 \pm 1.64^{\mathrm{cC}}$ & $38.81 \pm 2.52^{\mathrm{cB}}$ & $40.90 \pm 3.21^{\mathrm{cAB}}$ & $42.40 \pm 2.29^{\mathrm{cAB}}$ \\
Hydrolysate & $54.68 \pm 2.48^{\mathrm{aA}}$ & $38.81 \pm 3.22^{\mathrm{bcD}}$ & $46.82 \pm 2.12^{\mathrm{bC}}$ & $48.64 \pm 2.88^{\mathrm{abBC}}$ & $52.07 \pm 2.48^{\mathrm{abAB}}$ \\
$>10 \mathrm{kDa}$ & $47.05 \pm 3.01^{\mathrm{bA}}$ & $39.90 \pm 2.92^{\mathrm{bcB}}$ & $45.09 \pm 1.19^{\mathrm{bA}}$ & $47.99 \pm 1.50^{\mathrm{bA}}$ & $48.81 \pm 2.89^{\mathrm{bA}}$ \\
$5-10 \mathrm{kDa}$ & $53.50 \pm 2.18^{\mathrm{aA}}$ & $41.60 \pm 6.40^{\mathrm{abC}}$ & $43.51 \pm 1.94^{\mathrm{bBC}}$ & $47.90 \pm 1.45^{\mathrm{bABC}}$ & $49.22 \pm 1.89^{\mathrm{bAB}}$ \\
$3-5 \mathrm{kDa}$ & $57.28 \pm 0.83^{\mathrm{aA}}$ & $44.25 \pm 2.92^{\mathrm{abC}}$ & $51.29 \pm 1.94^{\mathrm{aB}}$ & $51.30 \pm 2.35^{\mathrm{aB}}$ & $52.48 \pm 1.59^{\mathrm{abB}}$ \\
$<3 \mathrm{kDa}$ & $56.61 \pm 2.36^{\mathrm{aA}}$ & $47.45 \pm 3.59^{\mathrm{aC}}$ & $50.78 \pm 2.26^{\mathrm{aBC}}$ & $53.13 \pm 3.40^{\mathrm{aAB}}$ & $54.92 \pm 3.55^{\mathrm{aAB}}$ \\
\hline
\end{tabular}

Mean \pm SD $(n=3)$. Values with different small letters in the same column are significantly different at $p<0.05$. Values with different capital letters in the same row are significantly different at $\mathrm{p}<0.05$.

TABLE 6. Foaming capacities of protein isolate, hydrolysate, and peptide fractions obtained from perilla seed meal at varying pH conditions.

\begin{tabular}{l|c|c|c|c|c}
\hline \multirow{2}{*}{ Fraction } & \multicolumn{5}{|c}{ Foaming capacity $(\mathrm{mL})$} \\
\cline { 2 - 6 } & $\mathrm{pH} 2.0$ & $\mathrm{pH} 4.0$ & $\mathrm{pH} 6.0$ & $\mathrm{pH} 8.0$ & $\mathrm{pH} 10.0$ \\
\hline Protein isolate & $4.70 \pm 0.26^{\mathrm{cAB}}$ & $3.70 \pm 0.26^{\mathrm{cC}}$ & $4.20 \pm 0.36^{\mathrm{CBC}}$ & $4.50 \pm 0.35^{\mathrm{dAB}}$ & $4.80 \pm 0.26^{\mathrm{CA}}$ \\
Hydrolysate & $6.10 \pm 0.10^{\mathrm{bA}}$ & $5.00 \pm 0.24^{\mathrm{bB}}$ & $5.73 \pm 0.14^{\mathrm{bA}}$ & $5.93 \pm 0.33^{\mathrm{cA}}$ & $6.10 \pm 0.10^{\mathrm{bA}}$ \\
$>10 \mathrm{kDa}$ & $7.00 \pm 1.00^{\mathrm{abAB}}$ & $5.23 \pm 0.31^{\mathrm{bC}}$ & $5.53 \pm 0.47^{\mathrm{bC}}$ & $5.93 \pm 0.40^{\mathrm{cBC}}$ & $7.10 \pm 0.56^{\mathrm{aA}}$ \\
$5-10 \mathrm{kDa}$ & $6.73 \pm 0.35^{\mathrm{abA}}$ & $5.40 \pm 0.20^{\mathrm{bB}}$ & $6.77 \pm 0.61^{\mathrm{aA}}$ & $6.63 \pm 0.564^{\mathrm{bA}}$ & $6.97 \pm 0.25^{\mathrm{aA}}$ \\
$3-5 \mathrm{kDa}$ & $7.29 \pm 0.30^{\mathrm{abA}}$ & $6.20 \pm 0.26^{\mathrm{aB}}$ & $7.10 \pm 0.35^{\mathrm{aA}}$ & $7.30 \pm 0.17^{\mathrm{aA}}$ & $7.46 \pm 0.42^{\mathrm{aA}}$ \\
$<3 \mathrm{kDa}$ & $7.10 \pm 0.53^{\mathrm{aA}}$ & $6.20 \pm 0.17^{\mathrm{aB}}$ & $7.01 \pm 0.32^{\mathrm{aAB}}$ & $7.29 \pm 0.30^{\mathrm{aA}}$ & $7.40 \pm 0.38^{\mathrm{aA}}$ \\
\hline
\end{tabular}

Mean \pm SD $(n=3)$. Values with different small letters in the same column are significantly different at $p<0.05$. Values with different capital letters in the same row are significantly different at $\mathrm{p}<0.05$.

of the ultrafiltered fractions ranged from $47.77 \pm 2.74 \%$ to $65.74 \pm 1.12 \%$. The hydrolysate and peptide fractions obtained via ultrafiltration showed higher emulsifying activities than those of the protein isolates. The emulsifying activity tended to increase with decreasing molecular weight of the peptides. All samples showed the highest emulsifying activity at $\mathrm{pH} 2.0$ and the lowest emulsifying activity at $\mathrm{pH}$ 4.0. The emulsifying activity tended to increase again at $\mathrm{pH}$ values above 6.0. In general, the emulsifying activity of proteins increased with higher protein solubility and was found to be significantly influenced by the $\mathrm{pH}$, temperature, and ionic strength conditions [Crenwelge et al., 1974; Kinsella 1979]. Wu et al. [1998] reported that the emulsifying activities of soy protein peptides prepared via papain modification and ultrafiltration were significantly higher compared to those of the protein isolates, which is consistent with our current findings. The above results suggested that hydrolysates with higher solubilities and smaller molecular weights promote diffusion and spread at oil-water interfaces [Wu et al., 1998]. In addition, the findings of Lui et al. [1989] suggested that ultrafiltration improves the emulsifying ability by increasing the number of peptides with emulsifying power, exposing hydrophobic residues of the proteins, and increasing the balance between hydrophilicity and hydrophobicity. Moreover, the findings of Wu et al. [1998] suggested that solubility and molecular size, rather than sur- face hydrophobicity, are the major factors responsible for the strong emulsifying activity of the small peptides.

The emulsion stability of the protein isolates ranged from $33.18 \pm 1.64 \%$ to $44.04 \pm 0.82 \%$. The emulsion stability of the hydrolysate ranged from $38.81 \pm 3.22 \%$ to $54.68 \pm 2.48 \%$ and that of the peptide fractions ranged from $39.90 \pm 2.92 \%$ to $57.28 \pm 0.83 \%$ (Table 5 ). The hydrolysate and peptide fractions showed relatively higher emulsion stabilities than those of the protein isolates. These results are consistent with those reported by Lui et al. [1989], in which the fractions fractionated via ultrafiltration demonstrated higher emulsion stabilities than soy. Yim \& Lee [2000] also reported that $<1 \mathrm{kDa}$ peptides obtained via fractionation of soybean protein hydrolysates obtained from proteolytic enzymes of Meju showed the highest emulsifying power and emulsion stability. Emulsions with small molecular oil droplet sizes were found to be more stable than those with larger droplets [Chove et al., 2002]. The emulsion stability of each sample at various $\mathrm{pH}$ values showed a similar trend with that of emulsifying activity. The emulsion stability was highest at $\mathrm{pH} 2.0$, except for the $>10 \mathrm{kDa}$ fraction, and lowest at $\mathrm{pH}$ 4.0. Chove et al. [2002] reported that soy protein isolates microfiltered using the $0.1-\mu \mathrm{m}$ membrane improved the emulsion-stabilizing ability of the resulting retentate. In addition, fractions richer in species with isoelectric point values of around 4.6 showed poor emulsifying stability in- 
TABLE 7. Foam stabilities of protein isolate, hydrolysate, and peptide fractions obtained from perilla seed meal at varying $\mathrm{pH}$ conditions.

\begin{tabular}{|c|c|c|c|c|c|c|c|c|c|c|}
\hline \multirow{3}{*}{ Fraction } & \multicolumn{10}{|c|}{ Foam stability (\%) } \\
\hline & \multicolumn{5}{|c|}{ Standing time (30 min) } & \multicolumn{5}{|c|}{ Standing time (60 min) } \\
\hline & $\mathrm{pH} 2.0$ & $\mathrm{pH} 4.0$ & pH 6.0 & pH 8.0 & pH 10.0 & $\mathrm{pH} 2.0$ & $\mathrm{pH} 4.0$ & pH 6.0 & pH 8.0 & pH 10.0 \\
\hline Protein isolate & $45.5 \pm 2.8^{\mathrm{bB}}$ & $0.0 \pm 0.0$ & $35.7 \pm 1.2^{\mathrm{bD}}$ & $51.1 \pm 2.5^{\mathrm{cA}}$ & $47.5 \pm 1.8^{\mathrm{dC}}$ & $32.0 \pm 1.5^{\mathrm{aB}}$ & $0.0 \pm 0.0$ & $28.3 \pm 1.6^{\mathrm{bC}}$ & $37.8 \pm 2.8^{\mathrm{cA}}$ & $34.2 \pm 0.7^{\mathrm{nsB}}$ \\
\hline Hydrolysate & $49.2 \pm 6.7^{\mathrm{bC}}$ & $0.0 \pm 0.0$ & $35.1 \pm 3.6^{\mathrm{bD}}$ & $77.0 \pm 2.4^{\mathrm{aA}}$ & $59.3 \pm 2.9^{\mathrm{bB}}$ & $32.8 \pm 0.7^{\mathrm{aB}}$ & $0.0 \pm 0.0$ & $33.3 \pm 0.5^{\mathrm{aC}}$ & $49.2 \pm 1.5^{\mathrm{aA}}$ & $33.9 \pm 1.5^{\mathrm{B}}$ \\
\hline$>10 \mathrm{kDa}$ & $46.7 \pm 2.9^{\mathrm{bA}}$ & $0.0 \pm 0.0$ & $34.5 \pm 2.5^{\mathrm{bC}}$ & $67.8 \pm 5.7^{\mathrm{bcA}}$ & $60.6 \pm 3.3^{\mathrm{bB}}$ & $20.0 \pm 2.5^{\mathrm{cC}}$ & $0.0 \pm 0.0$ & $23.6 \pm 2.2^{\mathrm{cC}}$ & $41.0 \pm 6.5^{\mathrm{bA}}$ & $31.0 \pm 2.5^{\mathrm{B}}$ \\
\hline $5-10 \mathrm{kDa}$ & $30.8 \pm 3.5^{\mathrm{cD}}$ & $0.0 \pm 0.0$ & $36.8 \pm 3.3^{\mathrm{bC}}$ & $68.2 \pm 4.2^{\mathrm{bA}}$ & $52.9 \pm 4.2^{\mathrm{cB}}$ & $26.2 \pm 1.8^{\mathrm{bB}}$ & $0.0 \pm 0.0$ & $17.6 \pm 1.3^{\mathrm{dC}}$ & $34.8 \pm 1.8^{\mathrm{cA}}$ & $32.9 \pm 2.8^{\mathrm{A}}$ \\
\hline $3-5 \mathrm{kDa}$ & $56.3 \pm 2.0^{\mathrm{aB}}$ & $0.0 \pm 0.0$ & $40.8 \pm 2.1^{\mathrm{aC}}$ & $71.2 \pm 2.5^{\mathrm{bA}}$ & $69.3 \pm 5.3^{\mathrm{aA}}$ & $32.4 \pm 2.9^{\mathrm{aB}}$ & $0.0 \pm 0.0$ & $12.7 \pm 1.1^{\mathrm{eC}}$ & $41.1 \pm 2.6^{\mathrm{bA}}$ & $32.0 \pm 4.3^{\mathrm{B}}$ \\
\hline$<3 \mathrm{kDa}$ & $48.2 \pm 1.8^{\mathrm{bC}}$ & $3.6 \pm 0.4^{\mathrm{E}}$ & $42.8 \pm 0.8^{\mathrm{aD}}$ & $72.1 \pm 1.5^{\mathrm{bA}}$ & $60.1 \pm 2.8^{\mathrm{bB}}$ & $30.8 \pm 5.3^{\mathrm{aB}}$ & $0.0 \pm 0.0$ & $28.3 \pm 2.9^{\mathrm{bC}}$ & $36.4 \pm 2.0^{\mathrm{cA}}$ & $35.8 \pm 4.0^{\mathrm{AB}}$ \\
\hline
\end{tabular}

Mean \pm SD $(n=3)$. Values with different small letters in the same column are significantly different at $\mathrm{p}<0.05$. Values with different capital letters in the row are significantly different at $\mathrm{p}<0.05$.

ns, no significant difference

dices and emulsifying activity indices. In the present study, the lowest emulsifying activity and emulsion stability values of all samples at $\mathrm{pH} 4.0$ were attributed to the isoelectric point of the PSM protein being $\mathrm{pH} 4.0$.

\section{Foaming properties}

Foaming properties are physicochemical characteristics of proteins that facilitate the formation and stabilization of foams. The foaming capacity and foam stability of protein isolate, hydrolysate, and peptide fractions at different $\mathrm{pH}$ values are shown in Tables 6 and 7, respectively. The foaming capacities of the hydrolysate $(5.00 \pm 0.24-6.10 \pm 0.10 \mathrm{~mL})$ and peptide fractions $(5.23 \pm 0.31-7.46 \pm 0.42 \mathrm{~mL})$ were higher than those of protein isolates $(3.70 \pm 0.26-4.80 \pm 0.26 \mathrm{~mL})$. This result might be due to the fact that the small peptides diffuse more rapidly to the air-water interface and encapsulate air bubbles, thereby developing a foam [Wierenga \& Gruppen, 2010]. The highest and lowest forming capacities of all samples were observed at $\mathrm{pH} 10.0$ and $\mathrm{pH} 4.0$, respectively, indicating that the foaming properties were significantly influenced by $\mathrm{pH}$. Adebowale \& Lawal [2003] reported that the foaming ability of a mucana bean protein

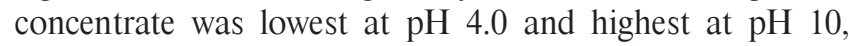
which was consistent with our result. Our current findings were also similar to these reported by Elderidge et al. [1963], in which the foaming capacity of soy protein was observed to be the lowest at the isoelectric point. The foaming capacity of protein improves the sensory properties of food, including the appearance and texture. Proteins with high foaming capabilities are used as foaming agents in the manufacture of food products and affect the texture and volume of bread [Kim \& Ahn, 2007]. The ultrafiltration process induces structural changes in the proteins and reduces S-S interactions, which also influence bubble formation [Bang et al., 1996]. In general, the foaming capacity of proteins was improved by increasing the structural flexibility via exposure of hydrophobic residues and by increasing the capacity to decrease surface tension [Mutilangi et al., 1996]. In addition, Kinsella \& Melachouris [1976] reported that protein hydrolysis exposes the hydrophobic groups of polypeptide and promotes the foam formation. Therefore, the strong foaming capacities of hydrolysate and peptide fractions from PSM protein were attributed to the exposure of hydrophobic residues to the enzymatic hydrolysis.

After standing for $30 \mathrm{~min}$ (Table 7), the foam stability was the highest in the $3-5 \mathrm{kDa}$ fraction, and the lowest in protein isolates at various $\mathrm{pH}$. The foam stability of each sample was high ranging from $51.1 \pm 2.5 \%$ to $77.0 \pm 2.4 \%$ at $\mathrm{pH} 8.0$, but foam of all samples except for $<3 \mathrm{kDa}$ fraction was destroyed at $\mathrm{pH}$ 4.0. PSM protein hydrolysate showed the highest foam stability, while $>10 \mathrm{kDa}$ fraction showed the lowest foam stability at all $\mathrm{pH}$ values except $\mathrm{pH} 6.0$ at standing for $60 \mathrm{~min}$. In addition, the foam stability according to $\mathrm{pH}$ was the highest at $\mathrm{pH} 8.0$ with the same tendency as at $30 \mathrm{~min}$, and no foam remained at $\mathrm{pH}$ 4.0. These results are similar to those reported by Klompong et al. [2017], in which the protein hydrolysates obtained from yellow stripe trevally (Selaroides leptolepis) showed the lowest foam stability at $\mathrm{pH} 4$, and foam stability of the hydrolysate was found to be higher at $\mathrm{pH} 6.0$ or higher and eventually decreased again at $\mathrm{pH} 10.0$. The low foam stability was concomitant with the low solubility at $\mathrm{pH} 4.0$. Protein solubility and the $\mathrm{pH}$ of the dispersing medium are important factors that determine the foaming properties of proteins, especially foam stability. The reduced foam stability at very acidic or alkaline $\mathrm{pH}$ could be attributed to the repulsion of peptides via ionic repulsion [Townsend \& Nakai, 1983; Klompong et al., 2017].

\section{CONCLUSIONS}

The protein hydrolysate and peptide fractions produced from perilla seed meal (PSM) were found to have a very high content of essential amino acids including lysine. In addition, protein hydrolysate and peptide fractions showed superior functionality compared to PSM protein isolates. Especially $<3 \mathrm{kDa}$ and $3-5 \mathrm{kDa}$ peptide fractions exhibited high solubility, oil absorption capacity, emulsifying activity, foam capacity, and foam stability. The results from this study indicate that peptides have the potential to be used as value-added food ingredients where functional properties 
are sought after (e.g. protein beverage formulations, bread, emulsion etc.). Furthermore, it is also important to invest their physiological activity to improve utilization as functional materials in food industry.

\section{RESERCH FUNDING}

This work was supported by the 2018 Yeungnam University Research Grant.

\section{CONFLICT OF INTERESTS}

Authors declare no conflict of interests.

\section{RERERENCES}

1. Adebowale, K.O., Lawal, O.S. (2003). Foaming, gelation and electrophoretic characteristics of mucana bean (Mucan pruriens) protein concentrates. Food Chemistry, 83(2), 237-246.

2. Bang, B.H., Seo, J.S., Jeon, E.J., Kim, K.P. (1996). Foaming capacity and foaming stability of protein recovered from red crab processing water. Korean Journal of Food Nutrition, 9 (3), 325-330.

3. Benítez, R., Ibarz, A., Pagan, J. (2008). Protein hydrolysates: processes and applications. Acta Bioquímica Clínica Latinoamericana, 42(2), 227-236.

4. Beuchat, L.R. (1977). Functional and electrophoretic characteristics of succinylated peanut flour proteins. Journal of Agricultural and Food Chemistry, 25(2), 258-261.

5. Bhattacharjee, S., Sultana, A., Sazzad, M.H., Islam, M.A., Ahtashom M.M., Asaduzzaman (2013). Analysis of the proximate composition and energy values of two varieties of onion ( $\mathrm{Al}$ lium cepa L.) bulbs of different origin: A comparative study. International Journal of Nutrition and Food Sciences, 2(5), 246-253.

6. Cabra, V., Arreguín, R., Farres, A. (2008). Emulsifying properties of proteins. Boletín de la Sociedad Química de México, 2(2), 80-89.

7. Chalamaiah, M., Dinesh Kumar, B., Hemalatha, R., Jyothirmayi, T. (2012). Fish protein hydrolysates: Proximate composition, amino acid composition, antioxidant activities and applications: A review. Food Chemistry, 135(4), 3020-3038.

8. Chove, B.E., Grandison, A.S., Lewis, M.J. (2002). Emulsifying properties of soy protein isolates obtained by microfiltration. Journal of the Science of Food and Agriculture, 82 (3), 267-272.

9. Córdova-Murueta, J.H., García-Carreño, F.L. (2002). Nutritive value of squid and hydrolyzed protein supplement in shrimp feed. Aquaculture, 210(1), 371-384.

10. Crenwelge, D.D., Dill, P., Tybor, P., Landmann, L.A. (1974). A comparison of the emulsification capacities of some protein concentrates. Journal of Food Science, 39(1), 175-177.

11. Dehnad, D., Jafari, S.M., Afrasiabi, M. (2016). Influence of drying on functional properties of food biopolymers: From traditional to novel dehydration techniques. Trends in Food Science \& Technology, 57, 116-131.

12. Di Bernardini, R., Harnedy, P., Bolton, D., Kerry, J., O’Neill, E., Mullen, A.M., Hayes, M. (2011). Antioxidant and antimicrobial peptidic hydrolysates from muscle protein sources and by-products. Food Chemistry, 124(4), 1296-1307.

13. Eldridge, A.C., Hall, P.K., Wolf, W.J. (1963). Stable foams from unhydrolyzed soybean protein. Food Technology, 17, 1592-1595
14. Gnanasambandam, R., Hettiarachchy, N.S. (1995). Protein concentrates from unstabilized and stabilized rice bran: preparation and properties. Journal of Food Science, 60(5), 1066-1069, 1074.

15. Hermansson, A.M.J. (1975). Functional properties of proteins for food-flow properties. Journal of Texture Studies, 5(4), 425-439.

16. Jang, H.R., Liceaga, A.M., Yoon, K.Y. (2016). Purification, characterisation and stability of an antioxidant peptide derived from sandfish (Arctoscopus japonicus) protein hydrolysates. Journal of Functional Foods, 20, 433-442

17. Kim, C.H., Ahn, M.S. (2007). Pysicochemical properties of whey protein isolate. Korean Journal of Food Science and Technology, 39(1), 50-54.

18. Kimatu, B.M.K., Zhao, L., Biao, Y. Ma, C., Yang, W., Pei, F., Hu, Q. (2017). Antioxidant potential of edible mushroom (Agaricus bisporus) protein hydrolysates and their ultrafiltration fractions. Food Chemistry, 230(1), 58-67.

19. Kinsella, J.E. (1979). Functional properties of soy proteins. Journal of the American Oil Chemists' Society, 56(3), 242-258.

20. Kinsella, J.E., Melachouris, N. (1976). Functional properties of proteins in foods: a survey. Critical Reviews in Food Science and Nutrition, 7(3), 219-280.

21. Klompong, V., Benjakul, S., Kantachote, D., Shahidi, F. (2017). Antioxidative activity and functional properties of protein hydrolysate of yellow stripe trevally (Selaroides leptolepis) as influenced by the degree of hydrolysis and enzyme type. Food Chemistry, 102(4), 1317-1327.

22. Lee, S.H., Cho, Y.J., Chun, S.S., Kim, Y.H., Choi, S. (1995). Functional properties of proteolytic enzyme-modified isolated sesame meal protein. Korean Journal of Food Science and Technology, 27(5), 708-715.

23. Lee, Y.I. (2015). Manufacturing soy-protein concentrates and isolates by membrane technology. International Journal of Agriculture Innovations and Research, 3(4), 1150-1158.

24. Lui, F.K., Nie, Y.H., Shen, B.Y. (1988). Manufacturing soy protein isolate by ultrafiltration. Proceedings of the World Congress on Vegetable Protein Utilization in Human Foods and Animal Feedstuffs. Singapore, October 1988, American Oil Chemists' Society, Champaign, IL, pp. 84-90.

25. Manak, L.T., Lawhon, J.T., Lusas, E.W. (1980). Functional potential of soy, cottonseed, and peanut protein isolates produced by industrial membrane systems. Journal of Food Science, 45(2), 236-238.

26. Megías, C., Pedroche, J., Yust, M.M., Alaiz, M., Girón-Calle, J., Millán, F., Vioque, J. (2009). Sunflower protein hydrolysates reduce cholesterol micellar solubility. Plant Foods Human Nutrition, 64(2), 86-93.

27. Meng, L., Lozano, Y., Bombarda, I., Gaydou, E.M., Li, B. (2009a). Polyphenol extraction from eight Perilla frutescens culivars. Comptes Rendus Chimie, 12(5), 602-611.

28. Meng, L., Lozano, Y., Bombarda, I., Gaydou, E.M., Li, B. (2009b). Antioxidant activities of polyphenols extracted from $\mathrm{Pe}$ rilla frutescens varieties. Molecules, 14(1), 133-140.

29. Mohammad, A. (2011). Health effects of omega-3,6,9 fatty acids: Perilla frutescens is a good example of plant oils. Oriental Pharmacy and Experimental Medicine, 11(1), 51-59.

30. Mutilangi, W.A.M., Panyam, D., Kilara, A. (1996). Functional properties of hydrolysates from proteolysis of heat-denatured whey protein isolate. Journal of Food Science, 61 (2), 270-275. 
31. Nalinanon, S., Benjakul, S., Kishimura, H., Shahidi, F. (2011). Functionalities and antioxidant properties of protein hydrolysates from the muscle of ornate threadfin bream treated with pepsin skipjack tuna. Food Chemistry, 124(4), 1354-1362.

32. Nguyen, E., Jones, O., Kim, Y.H.B., Martin-Gonzalez, S., Liceaga, A.M. (2017). Impact of microwave-assisted enzymatic hydrolysis on functional and antioxidant properties of rainbow trout $\mathrm{On}$ corhynchus mykiss by-products. Fisheries Science, 83(2), 317-331.

33. Park, B.Y., Yoon, K.Y. (2018). Conditions for hydrolysis of perilla seed meal protein for producing hydrolysates and ultrafiltered peptides and their antioxidant activity. Korean Journal of Food Preservation, 25(5), 605-612.

34. Park, J.Y., Yoon K.Y. (2014). Comparison of the nutrient composition and quality of the root of Allium hookeri grown in Korea and Myanmar. Korean Journal of Food Science and Technology, 45(5), 544-548.

35. Pearson, A.M. (1994). Soy proteins. In Nakamura (Ed.), Developments in Food Engineering. Blackie Academic \& Professional Publishing Co. London, U.K. pp. 67-104.

36. Sarabandi, K., Mahoonak, A.S., Hamishekar, H., Ghorbni, M., Jafari, S.M. (2018). Microencapsulation of casein hydrolysates: Physicochemical, antioxidant and microstructure properties. Journal of Food Engineering, 237, 86-95.

37. Sathe, S.K., Salunkhe, D.K. (1981). Functional properties of the great northern bean (Phaseolus vulgaris L.) proteins: emulsion, foaming, viscosity, and gelation properties. Journal of Food Science, 46(1), 71-81.
38. Schmidl, M.K., Taylor, S.L., Nordlee J.A. (1994). Use of hydrolysate-based products in special medical diets. Food Technology, 48(10), 77-85.

39. Singh, N., Kaur, M., Sandhu, K.S. (2005). Physicochemical and functional properties of freeze-dried and oven dried corn gluten meals. Drying Technology, 23(4), 975-988.

40. Tan, E.S., Ngoh, Y.Y., Gan, C.Y. (2014). A comparative study of physicochemical characteristics and functionalities of pinto bean protein isolate (PBPI) against the soybean protein isolate (SPI) after the extraction optimization. Food Chemistry, 152(1), 447-455.

41. Townsend, A.A., Nakai, S. (1983). Relationships between hydrophobicity and foaming characteristics of food proteins. Journal of Food Science, 48(2), 588-594.

42. Wierenga, P., Gruppen, H. (2010). New views on foams from protein solutions. Current Opinion in Colloid \& Interface Science, 15(5), 365-373.

43. Wu, W.U., Hettiarachchy, N.S., Qi, M. (1998). Hydrophobicity, solubility, and emulsifying properties of soy protein peptides prepared by papain modification and ultrafiltration. Journal of the American Oil Chemists' Society, 75(7), 845-850.

44. Yim, M.H., Lee, J.H. (2000). Functional properties of fractionated soy protein isolates by protease from Meju. Food Science and Biotechnology, 9(4), 253-257.

Submitted: 31 October 2018. Revised: 7 January 2019. Accepted: 18 January 2019. Published on-line: 1 March 2019. 